ARTICLE

DOI: $10.1038 /$ s41467-018-06311-0

\title{
Copper-on-nitride enhances the stable electrosynthesis of multi-carbon products from $\mathrm{CO}_{2}$
}

Zhi-Qin Liang ${ }^{1,2}$, Tao-Tao Zhuang ${ }^{1}$, Ali Seifitokaldani ${ }^{1}$, Jun Li (i) ${ }^{1,3}$, Chun-Wei Huang ${ }^{4}$, Chih-Shan Tan ${ }^{1}$, Yi Li $^{5}$, Phil De Luna ${ }^{6}{ }^{6}$, Cao Thang Dinh ${ }^{1}$, Yongfeng $\mathrm{Hu}^{7}$, Qunfeng Xiao ${ }^{7}$, Pei-Lun Hsieh ${ }^{8}$, Yuhang Wang ${ }^{1}$,

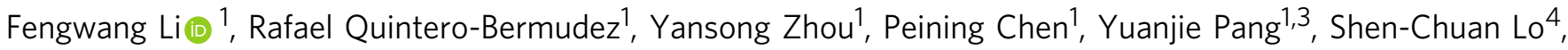
Lih-Juann Chen ${ }^{8}$, Hairen Tan (1) ${ }^{1}$, Zheng $\mathrm{Xu}^{2}$, Suling Zhao ${ }^{2}$, David Sinton (1) ${ }^{3}$ \& Edward H. Sargent (i) ${ }^{1}$

Copper-based materials are promising electrocatalysts for $\mathrm{CO}_{2}$ reduction. Prior studies show that the mixture of copper $(\mathrm{I})$ and copper $(0)$ at the catalyst surface enhances multi-carbon products from $\mathrm{CO}_{2}$ reduction; however, the stable presence of copper (I) remains the subject of debate. Here we report a copper on copper (I) composite that stabilizes copper (I) during $\mathrm{CO}_{2}$ reduction through the use of copper nitride as an underlying copper (I) species. We synthesize a copper-on-nitride catalyst that exhibits a Faradaic efficiency of $64 \pm 2 \%$ for $\mathrm{C}_{2+}$ products. We achieve a 40 -fold enhancement in the ratio of $\mathrm{C}_{2+}$ to the competing $\mathrm{CH}_{4}$ compared to the case of pure copper. We further show that the copper-on-nitride catalyst performs stable $\mathrm{CO}_{2}$ reduction over $30 \mathrm{~h}$. Mechanistic studies suggest that the use of copper nitride contributes to reducing the $\mathrm{CO}$ dimerization energy barrier-a rate-limiting step in $\mathrm{CO}_{2}$ reduction to multi-carbon products.

\footnotetext{
${ }^{1}$ Department of Electrical and Computer Engineering, University of Toronto, 10 King's College Road, Toronto, ON M5S 3G4, Canada. ${ }^{2}$ Key Laboratory of Luminescence and Optical Information, Beijing Jiaotong University, Ministry of Education, Beijing 100044, China. ${ }^{3}$ Department of Mechanical and Industrial Engineering, University of Toronto, 5 King's College Road, Toronto, ON M5S 3G8, Canada. ${ }^{4}$ Material and Chemical Research Laboratories, Industrial Technology Research Institute, Hsinchu 31040, Taiwan. ${ }^{5}$ Division of Nanomaterials \& Chemistry, Hefei National Research Center for Physical Sciences at the Microscale, CAS Center for Excellence in Nanoscience, Hefei Science Center of CAS, Collaborative Innovation Center of Suzhou Nano Science and Technology, Department of Chemistry, University of Science and Technology of China, Hefei, Anhui 230026, China. ${ }^{6}$ Department of Materials Science and Engineering, University of Toronto, 184 College Street, Toronto, ON M5S 3E4, Canada. ${ }^{7}$ Canadian Light Source (CLS), 44 Innovation Boulevard, Saskatoon, SK S7N 2V3, Canada. ${ }^{8}$ Department of Materials Science and Engineering, National Tsing Hua University, Hsinchu 30013, Taiwan. These authors contributed equally: Zhi-Qin Liang, Tao-Tao Zhuang, Ali Seifitokaldani. Correspondence and requests for materials should be addressed to E.H.S. (email: ted.sargent@utoronto.ca)
} 
E lectrocatalytic $\mathrm{CO}_{2}$ reduction has been investigated extensively based on metals such as $\mathrm{Au}, \mathrm{Ag}, \mathrm{Sn}, \mathrm{Zn}, \mathrm{In}, \mathrm{Pd}, \mathrm{Cu}$, and their associated compounds ${ }^{1-4}$. Among these materials, $\mathrm{Cu}$-based catalysts are promising for olefin and oxygenate production thanks to their moderate $\mathrm{CO}$ binding energies ${ }^{5,6}$. Multicarbon products such as ethylene $\left(\mathrm{C}_{2} \mathrm{H}_{4}\right)$, ethanol $\left(\mathrm{C}_{2} \mathrm{H}_{5} \mathrm{OH}\right)$, and n-propanol $\left(\mathrm{C}_{3} \mathrm{H}_{7} \mathrm{OH}\right)$ are of great interest: $\mathrm{C}_{2} \mathrm{H}_{4}$, for example, is a valuable precursor in the manufacture of polymers ${ }^{7} ; \mathrm{C}_{2} \mathrm{H}_{5} \mathrm{OH}$ can be directly used as fuel ${ }^{8}$; and $\mathrm{C}_{3} \mathrm{H}_{7} \mathrm{OH}$ has a higher mass energy density $\left(30.94 \mathrm{~kJ} \mathrm{~g}^{-1}\right)^{9,10}$ than does gasoline ${ }^{11}$. Furthermore, renewables-derived $\mathrm{C}_{2} \mathrm{H}_{5} \mathrm{OH}$ and $\mathrm{C}_{3} \mathrm{H}_{7} \mathrm{OH}$ can each be blended with gasoline to deliver a clean fuel ${ }^{12}$.

Polycrystalline $\mathrm{Cu}$ metal is known to produce $\mathrm{CH}_{4}$ with high selectivity ${ }^{4,13}$, whereas oxide-derived $\mathrm{Cu}$ favors $\mathrm{C}_{2+}$ products ${ }^{14-17}$, a fact attributed to the effects of grain boundaries ${ }^{18-20}$, high-local $\mathrm{pH}^{21,22}$, and residual oxygen $14,23,24$. Certain prior computational studies have suggested that the $\mathrm{Cu}^{+} / \mathrm{Cu}^{0}$ mixture synergistically promotes $\mathrm{CO}_{2}$ reduction to $\mathrm{C}_{2}$ products due to $\mathrm{CO}_{2}$ activation and $\mathrm{CO}$ dimerization ${ }^{25,26}$. Experimentally, however, the stable presence of the active $\mathrm{Cu}^{+}$species during $\mathrm{CO}_{2}$ reduction remains the subject of debate 27 .

$\mathrm{A} \mathrm{Cu}^{+}-\mathrm{Cu}^{0}$ core-shell structured catalyst offers an architecture wherein stable $\mathrm{Cu}^{0}$ deposited on top of a $\mathrm{Cu}^{+}$support protects from further reduction. Recently, core-shell catalysts have been widely investigated in electrocatalysis and have achieved significantly improved activity and kinetics ${ }^{28-35}$. The core-support interactions modify the electronic structure of the surface catalyst, influencing the chemisorption of the intermediates in the electrocatalytic reaction ${ }^{31}$. Copper (I) oxide $\left(\mathrm{Cu}_{2} \mathrm{O}\right)$, which has been mostly used as a precursor to $\mathrm{Cu}$-based $\mathrm{CO}_{2}$ reduction catalysts ${ }^{14,17-19,23,24}$, is a candidate as a $\mathrm{Cu}^{+}$support; however, $\mathrm{Cu}^{+}$ from $\mathrm{Cu}_{2} \mathrm{O}$ is unstable under $\mathrm{CO}_{2}$ reduction conditions. Previous reports suggest that transition metal nitrides can be employed not only as a stable catalytic active species, but also as supports ${ }^{36}$.

Here we sought therefore to investigate whether copper (I) nitride $\left(\mathrm{Cu}_{3} \mathrm{~N}\right)$ could be used as $\mathrm{Cu}^{+}$support during $\mathrm{CO}_{2}$ reduction. We hypothesize that the $\mathrm{Cu}_{3} \mathrm{~N}$ support affects the electronic structure and oxidation state of the surface $\mathrm{Cu}$, decreasing the energy barrier associated with $\mathrm{CO}$ dimerization during $\mathrm{CO}_{2}$ reduction. This, together with the prolonged presence of $\mathrm{Cu}^{+}$over time, could allow for the realization of increasedstability $\mathrm{C}_{2+}$ electrosynthesis systems under $\mathrm{CO}_{2}$ reduction conditions.

\section{Results}

Synthesis and structural characterization. In order to challenge our hypothesis, we set out to synthesize $\mathrm{Cu}$ deposited on $\mathrm{Cu}_{3} \mathrm{~N}$ $\left(\mathrm{Cu}-\mathrm{on}-\mathrm{Cu}_{3} \mathrm{~N}\right)$ catalyst as depicted in Fig. la. We first synthesized $\mathrm{Cu}_{3} \mathrm{~N}$ nanocrystals capped with long-chain octadecylamine (ODA) ligands ${ }^{37}$. We then performed a ligand exchange using short-chain azide $\left(\mathrm{N}_{3}{ }^{-}\right)$to replace the ODA. An outer oxide was formed at the surface of $\mathrm{Cu}_{3} \mathrm{~N}$ nanocrystals by exposing samples to ambient air during the ligand exchange process. These nanocrystals then went through an initial electroreduction process: we swept the cyclic voltammetry (CV) curve from 0 to $-1.75 \mathrm{~V}$ vs. $\mathrm{RHE}$ to obtain the active $\mathrm{Cu}-\mathrm{on}-\mathrm{Cu}_{3} \mathrm{~N}$ catalyst.

To investigate surface electronic properties, we conducted Xray photoelectron spectroscopy (XPS) measurements of the samples (Fig. 1b). In the case of the $\mathrm{Cu}_{3} \mathrm{~N}$ nanocrystals capped with ODA (Fig. 1b-i), the spectra of $\mathrm{Cu} 2 \mathrm{p}$ and Auger $\mathrm{Cu}$ LMM confirm a preponderance of $\mathrm{Cu}^{+38}$. The sharp peak of $\mathrm{N}$ at a binding energy of $399 \mathrm{eV}$ is consistent with that of the metal nitride ${ }^{37,39}$. Furthermore, X-ray diffraction (XRD) attests to the formation of $\mathrm{Cu}_{3} \mathrm{~N}$ nanocrystals (Supplementary Fig. 1) ${ }^{37}$.
Implementing the ligand exchange (Fig. 1b-ii and Supplementary Fig. 2) led to a different $\mathrm{Cu}$ composition compared to that before ligand exchange. A mixture of $\mathrm{Cu}^{2+}$ and $\mathrm{Cu}^{+}$are present as observed in $\mathrm{Cu} 2 \mathrm{p}$ and LMM spectra ${ }^{38}$, which suggests that copper (II) oxide $(\mathrm{CuO})$ is formed in ambient air during the $\mathrm{Cu}_{3} \mathrm{~N}$ ligand exchange. The new peak in the $\mathrm{N} 1 \mathrm{~s}$ spectrum located at $403.1 \mathrm{eV}$ aligns with that of the $\mathrm{N}_{3}{ }^{-}$group in the ligand at the nanocrystal surface ${ }^{40}$. When taken together with Fouriertransform infrared (FTIR) spectra (Supplementary Fig. 3), these findings reveal that the ODA organic ligands are completely replaced by the $\mathrm{N}_{3}{ }^{-}$short ligands. In addition, the $\mathrm{Cu} 2 \mathrm{p}$ peak areas indicate that the content of $\mathrm{Cu}^{2+}$ is significantly higher relative to the $\mathrm{Cu}^{+}$: we propose that $\mathrm{CuO}$ exists at the surface and substantially encompasses the $\mathrm{Cu}_{3} \mathrm{~N}$. As shown in the $\mathrm{O} 1 \mathrm{~s}$ spectrum (Supplementary Fig. 4), the dominant peak at $513.3 \mathrm{eV}$ was assigned to $\mathrm{O}$ species in the surface $\mathrm{CuO}$ on the sample.

After initial reduction (Fig. 1b-iii), the $\mathrm{Cu}$ spectra show the presence of both $\mathrm{Cu}^{+}$and $\mathrm{Cu}^{0}$, which indicates that the surface of the catalyst was reduced to $\mathrm{Cu}$. The $\mathrm{N} 1$ s peak at $399 \mathrm{eV}$ remains after reduction, indicating that the $\mathrm{Cu}_{3} \mathrm{~N}$ phase is intact. The disappearance of the $\mathrm{N}$ peak at $403.1 \mathrm{eV}$, which is the characteristic of the $\mathrm{N}_{3}-$ ligands, can be ascribed to the weak electrostatic interaction between the ligands and the surface of the $\mathrm{Cu}_{3} \mathrm{~N}$ nanocrystals when a potential was applied.

We used transmission electron microscopy (TEM) to investigate further the structure of the catalyst (Supplementary Fig. 5). Before ligand exchange, $\mathrm{Cu}_{3} \mathrm{~N}$ nanocrystals have an average diameter of $30 \mathrm{~nm}$. After ligand exchange, a reduced spacing between the nanocrystals is observed, similar to the case of quantum dot ligand exchanges ${ }^{41}$.

The local atomic-scale elemental composition on individual $\mathrm{Cu}-\mathrm{on}-\mathrm{Cu}_{3} \mathrm{~N}$ nanoparticle was further examined (Fig. 2a, b). From high-resolution transmission electron microscopy with electron energy loss spectroscopy (HRTEM-EELS, Fig. 2c), we observed that $\mathrm{Cu}$ was distributed across the volume of each nanoparticle; while $\mathrm{N}$ was concentrated in the core and was notably lower at the surface. The catalyst surface exhibited indications of surface reconstruction following operation under reducing conditions ${ }^{42}$. Our analysis of HRTEM-EELS data indicates $a<=3 \mathrm{~nm}$ surface $\mathrm{Cu}$ layer on top of $\mathrm{Cu}_{3} \mathrm{~N}$ (Supplementary Fig. 6).

We further investigated the distribution of $\mathrm{N}$ using EELS spectra. In a given nanoparticle, looking at two different positions (Fig. 2d), we found that for point A (inner), a strong absorption feature starting from $401 \mathrm{eV}$ was obtained, consistent with the $\mathrm{N}$ K-shell absorption edge ${ }^{43}$. No obvious absorption signal was observed for point $\mathrm{B}$ (surface), indicating no $\mathrm{N}$ at the surface. These observations indicate a $\mathrm{Cu}$-on- $\mathrm{Cu}_{3} \mathrm{~N}$ structure.

We synthesized $\mathrm{Cu}$ deposited on $\mathrm{Cu}_{2} \mathrm{O}\left(\mathrm{Cu}-\right.$ on- $\left.-\mathrm{Cu}_{2} \mathrm{O}\right)$ and pure $\mathrm{Cu}$ catalysts as control samples using a process similar to the synthesis of the $\mathrm{Cu}-\mathrm{on}-\mathrm{Cu}_{3} \mathrm{~N}$ catalyst. $\mathrm{XRD}$ patterns confirm the formation of $\mathrm{Cu}$-on- $\mathrm{Cu}_{2} \mathrm{O}$ and pure $\mathrm{Cu}$ after electroreduction (Supplementary Fig. $7 \mathrm{a}-\mathrm{c}$ ). Their morphology and size are similar to those of the $\mathrm{Cu}-$ on- $\mathrm{Cu}_{3} \mathrm{~N}$ catalyst (Supplementary Fig. $7 \mathrm{~b}-\mathrm{d}$ ). Double-layer capacitance measurements yielded electrochemical roughness factors of 9.7, 8.0, and 9.3 for the $\mathrm{Cu}$-on- $\mathrm{Cu}_{3} \mathrm{~N}, \mathrm{Cu}$-on$\mathrm{Cu}_{2} \mathrm{O}$, and $\mathrm{Cu}$ catalysts, respectively, indicating similar surface: geometric area ratios (Supplementary Fig. 8 and Supplementary Table 1).

We also obtained valence band spectra (VBS) to examine differences in the valence electronic structure between the $\mathrm{Cu}$ and the composite (Supplementary Fig. 9). Comparing with the case of pure $\mathrm{Cu}$, we found that the Fermi-level $\left(E_{\mathrm{F}}\right)$ shifted toward the $\mathrm{VB}_{\mathrm{m}}$ by $0.33 \mathrm{eV}$ for $\mathrm{Cu}$-on- $\mathrm{Cu}_{3} \mathrm{~N}$ and $0.08 \mathrm{eV}$ for $\mathrm{Cu}$-on- $\mathrm{Cu}_{2} \mathrm{O}$, respectively, indicating that the core-level $\mathrm{Cu}_{3} \mathrm{~N}$ and $\mathrm{Cu} 2 \mathrm{O}$ supports have an effect on the electronic structure of the surface $\mathrm{Cu}$. 


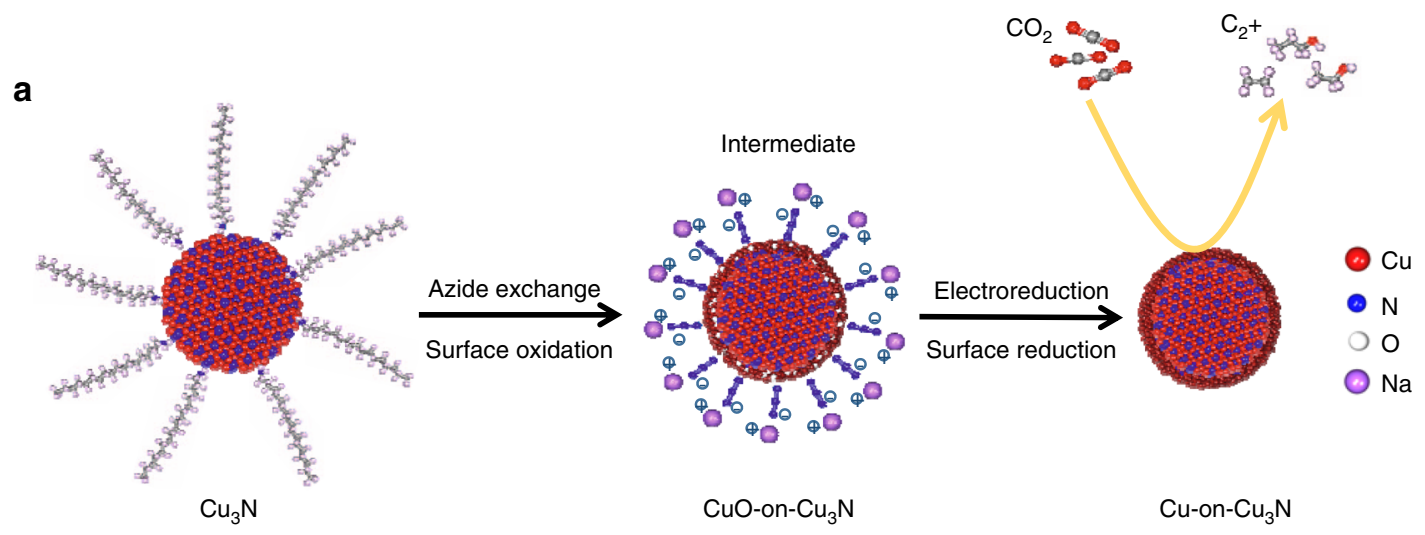

b
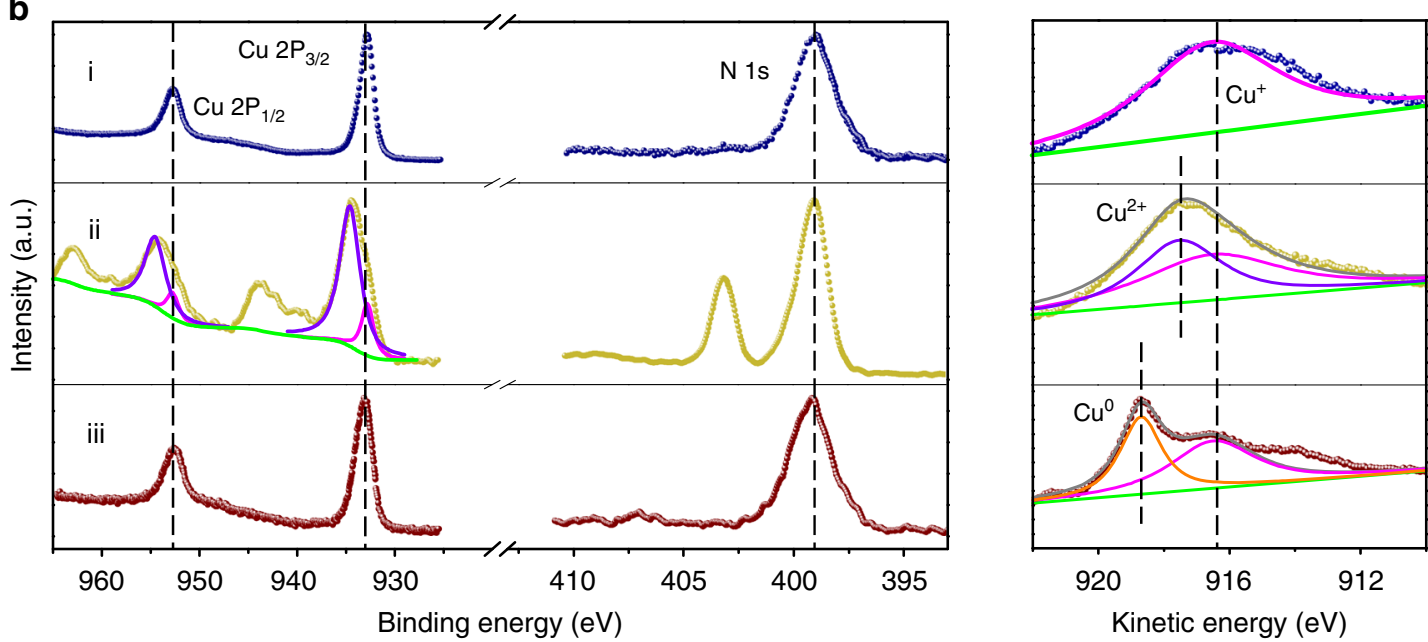

Fig. 1 Electrocatalyst design and the corresponding XPS characterization. a Schematic of preparing the Cu-on-Cu $\mathrm{N}_{3} \mathrm{Natalyst}$. $\mathbf{b}$ XPS spectra of $\mathrm{Cu} 2 \mathrm{p}$, N $1 \mathrm{~s}$, and Auger $\mathrm{Cu} L M M$ of the $\mathrm{Cu}_{3} \mathrm{~N}$ nanocrystals with long organic ODA (i), the $\mathrm{Cu}_{3} \mathrm{~N}$ nanocrystals with an oxide layer after $\mathrm{N}_{3}{ }^{-}$ligand exchange (ii), and the $\mathrm{Cu}$-on- $\mathrm{Cu}_{3} \mathrm{~N}$ composite after initial electroreduction (iii)
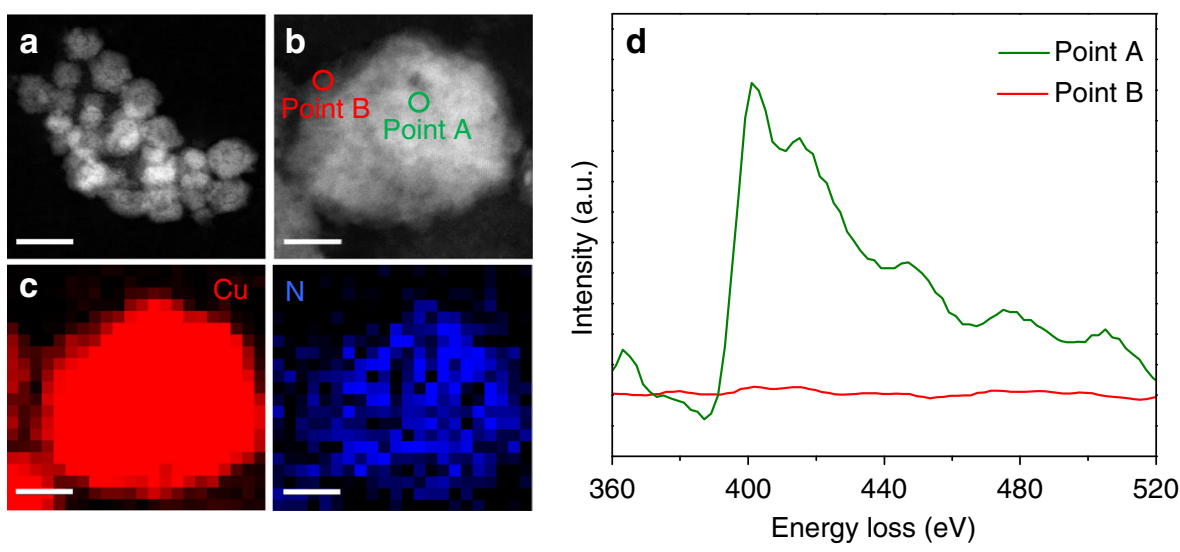

Fig. 2 TEM characterization of the Cu-on-Cu $\mathrm{N}$ catalyst. $\mathbf{a}$, b HADDF-STEM images. c STEM-EELS $\mathrm{Cu}$ and N Element mapping of one individual particle in $\mathbf{b}$, d, EEL spectra of element $\mathrm{N}$ K-edge circled as point $A$ and point $B$ in $\mathbf{b}$. The scale bars are $50 \mathrm{~nm}$ in $\mathbf{a}$, and $10 \mathrm{~nm}$ in $\mathbf{b}$ and $\mathbf{c}$

Spectroscopic characterization. To investigate the structure and chemical state of the active catalysts with time evolution under $\mathrm{CO}_{2}$ reduction, we obtained in situ X-ray absorption spectra (XAS) of the three catalysts at $-0.95 \mathrm{~V}$ vs. RHE during $\mathrm{CO}_{2}$ reduction.

As depicted in Fig. 3a, b, the $\mathrm{Cu}$ K-edge XAS spectrum of the as-prepared $\mathrm{Cu}-\mathrm{on}-\mathrm{Cu}_{3} \mathrm{~N}$ catalyst presents an absorption edge between $\mathrm{Cu}(8979 \mathrm{eV})$ and $\mathrm{Cu}_{3} \mathrm{~N}(8980.5 \mathrm{eV})$-and in particular exhibits a prominent shoulder at $8980.0 \mathrm{eV}$. Over the course of $\mathrm{CO}_{2}$ reduction, both $\mathrm{Cu}$ and $\mathrm{Cu}_{3} \mathrm{~N}$ features are still present, with a shoulder energy at $8979.4 \mathrm{eV}$ after $2 \mathrm{~h}$. In contrast, the $\mathrm{Cu}$-on- $\mathrm{Cu}_{2} \mathrm{O}$ catalyst shows a prominent metallic $\mathrm{Cu}$ feature after $1 \mathrm{~h}$ (Supplementary Fig. 10a). Pure $\mathrm{Cu}$ presents a metallic $\mathrm{Cu}$ feature under $\mathrm{CO}_{2}$ reduction (Supplementary Fig. 10b).

To gain more insight into the role of the $\mathrm{Cu}^{+}$support, we acquired in situ $\mathrm{Cu}$ K-edge spectra of Cu-on- $\mathrm{Cu}_{3} \mathrm{~N}$ and $\mathrm{Cu}$-on$\mathrm{Cu}_{2} \mathrm{O}$ catalysts following 30 min under $\mathrm{CO}_{2}$ reduction (Fig. $3 \mathrm{c}$ ). 


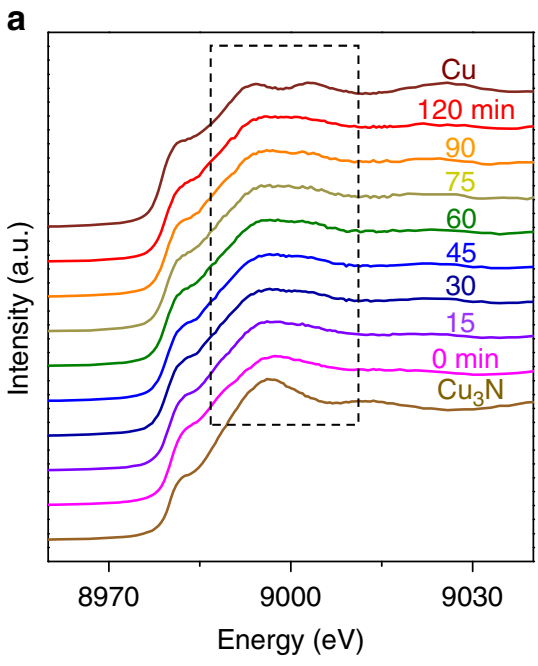

C

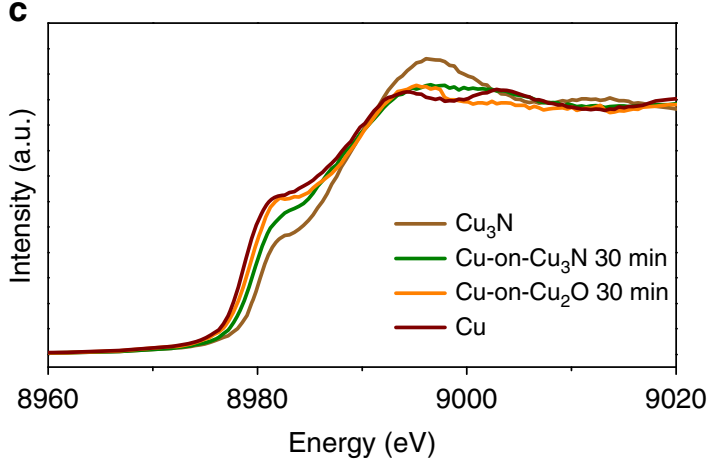

b

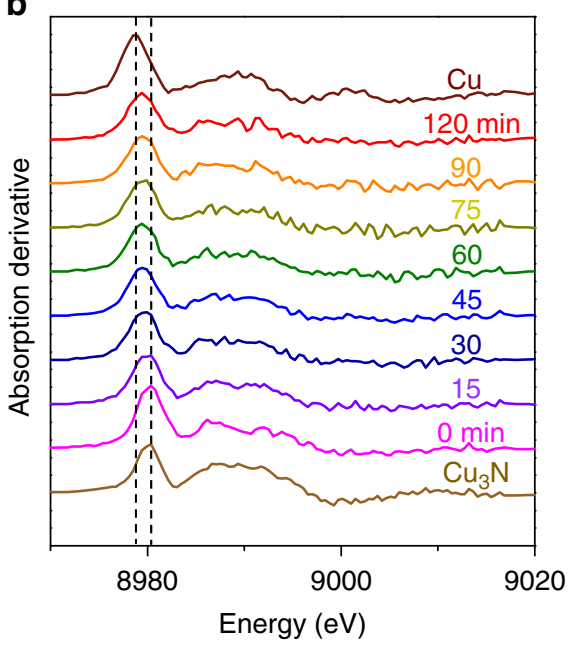

d

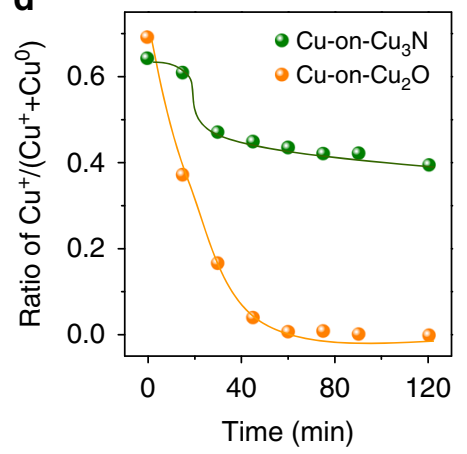

Fig. 3 In situ characterization of the structure and chemical state for the catalysts during $\mathrm{CO}_{2}$ reduction. a $\mathrm{Cu}$ K-edge XAS spectra of the $\mathrm{Cu}$-on- $\mathrm{Cu} 3 \mathrm{~N}$ catalyst as function of reaction time at $-0.95 \mathrm{~V}$ vs RHE. $\mathbf{b}$ The first derivatives of the spectra in $\mathbf{a}$. $\mathbf{c}$ In situ Cu K-edge spectra during the initial 30 min on the catalysts: $\mathrm{Cu}-\mathrm{on}-\mathrm{Cu}_{3} \mathrm{~N}$ (green) and $\mathrm{Cu}-\mathrm{on}-\mathrm{Cu}_{2} \mathrm{O}$ (orange). Spectra of $\mathrm{Cu}$ (red) and $\mathrm{Cu}_{3} \mathrm{~N}$ (yellow) are also listed as references. $\mathbf{d}$ Ratio of $\mathrm{Cu}+$ relative to the reaction time at $-0.95 \mathrm{~V}$ vs $\mathrm{RHE}$

We found that the absorption edges of the two catalysts are between $\mathrm{Cu}^{+}$and $\mathrm{Cu}^{0}$, indicating the presence of a mixture during the reaction. However, the absorption edge of $\mathrm{Cu}$-on$\mathrm{Cu}_{2} \mathrm{O}$ was at a lower energy than that of $\mathrm{Cu}-$ on- $-\mathrm{Cu}_{3} \mathrm{~N}$, with energies at $8979.4 \mathrm{eV}$ and $8979.8 \mathrm{eV}$, respectively. We also calculated the ratio of $\mathrm{Cu}$ oxidation states as function of the reaction time (Fig. 3d). The $\mathrm{Cu}-\mathrm{on}-\mathrm{Cu}_{3} \mathrm{~N}$ catalyst shows that the structure becomes stable with $\mathrm{Cu}_{3} \mathrm{~N}$ and $\mathrm{Cu}$ after the initial 60 min, while $\mathrm{Cu}$-on- $\mathrm{Cu}_{2} \mathrm{O}$ only presents the $\mathrm{Cu}$ component after $1 \mathrm{~h}$. This observation indicates suppression of the partial reduction of the catalyst when we use the $\mathrm{Cu}_{3} \mathrm{~N}$ support.

We sought a method to probe with greater surface-specificity catalyst as function of reaction time. We acquired angle-resolved XPS (ARXPS) at a $20^{\circ}$ emission angle relative to the sample normal (Supplementary Fig. 11a). The detection depth is below $2 \mathrm{~nm}^{44}$. Cu LMM spectra (Supplementary Fig. 11b-f, left column) indicate the presence of $\mathrm{Cu}^{+}$and $\mathrm{Cu}^{0}$, and the $\mathrm{N} 1 \mathrm{~s}$ spectra (Supplementary Fig. $11 \mathrm{~b}-\mathrm{f}$, right column) are consistent with the spectrum of metal nitride, indicating the presence of $\mathrm{Cu}_{3} \mathrm{~N}$ in the first $\sim 2 \mathrm{~nm}$ of the surface over the course of $\mathrm{CO}_{2}$ reduction. In the initial $60 \mathrm{~min}, \mathrm{Cu}^{0}$ content increased and $\mathrm{Cu}_{3} \mathrm{~N}$ content decreased; thereafter, such as following a 2-h reaction, the catalyst gradually reached a stable surface composition. This result agrees with the observed in situ XAS data (Fig. 3d).

Both in situ XAS and ex situ ARXPS indicate the presence of $\mathrm{Cu}^{+}$following $\mathrm{CO}_{2}$ reduction. Further, the $\mathrm{N}$ signal suggests the presence of $\mathrm{Cu}_{3} \mathrm{~N}$, and STEM-EELS mapping (Supplementary Fig. 6) shows evidence of $\mathrm{Cu}_{3} \mathrm{~N}$ in the subsurface layer following
$\mathrm{CO}_{2}$ reduction. Nevertheless, we point out also that XAS has a bulk penetration depth; and that air-sensitive $\mathrm{Cu}$ complicates the interpretation of the ARXPS studies herein. For these reasons, direct and unambiguous confirmation of the presence of $\mathrm{Cu}^{+}$at the surface of the catalyst remains an ongoing opportunity for further advances in the field of $\mathrm{Cu}$-based electrocatalysis and model development.

$\mathrm{CO}_{2}$ electroreduction performance. To verify the effect of the $\mathrm{Cu}^{+}$support on the surface catalyst, we carried out $\mathrm{CO}_{2}$ reduction using the $\mathrm{Cu}$-on- $\mathrm{Cu}_{3} \mathrm{~N}, \mathrm{Cu}$-on- $\mathrm{Cu}_{2} \mathrm{O}$, and pure $\mathrm{Cu}$ catalysts, respectively. To analyze the selectivity toward various products with different applied potentials, we performed stepped-potential electrolysis between -0.55 and $-1.45 \mathrm{~V}$ vs RHE (with $i R$ correction in Supplementary Fig. 12).

$\mathrm{Cu}$-on- $\mathrm{Cu}_{3} \mathrm{~N}$ gives the highest $\mathrm{C}_{2+}$ production among the three catalysts (Fig. 4a, b). When the applied potential is less negative than $-0.65 \mathrm{~V}$ vs $\mathrm{RHE}, \mathrm{CH}_{4}$, and $\mathrm{HCOOH}$ are the main products; whereas, when we sweep toward more strongly negative potentials, we obtain production of reduced $\mathrm{C}_{2}+$ species, such as $\mathrm{C}_{2} \mathrm{H}_{4}, \mathrm{C}_{2} \mathrm{H}_{5} \mathrm{OH}$, and $\mathrm{C}_{3} \mathrm{H}_{7} \mathrm{OH}$. This indicates $\mathrm{CO}$ dimerization beyond the potential of $-0.65 \mathrm{~V}$ vs. RHE (Supplementary Figs. 13a, 14 and Supplementary Table 2). The highest FE for total $\mathrm{C}_{2+}$ reaches $64 \pm 2 \%$ at $-0.95 \mathrm{~V}$ vs. $\mathrm{RHE}$, with $\mathrm{C}_{2} \mathrm{H}_{4}, \mathrm{C}_{2} \mathrm{H}_{5} \mathrm{OH}$, and $\mathrm{C}_{3} \mathrm{H}_{7} \mathrm{OH}$ accounting for $39 \pm 2 \%, 19 \pm 1 \%$, and $6 \pm 1 \%$, respectively.

The $\mathrm{Cu}$-on- $\mathrm{Cu}_{3} \mathrm{~N}$ catalyst achieves a 6.3 -fold enhancement in the ratio of $\mathrm{C}_{2+}$ to $\mathrm{CH}_{4}$ compared to $\mathrm{Cu}$-on- $\mathrm{Cu}_{2} \mathrm{O}$; and a 40 -fold 
a

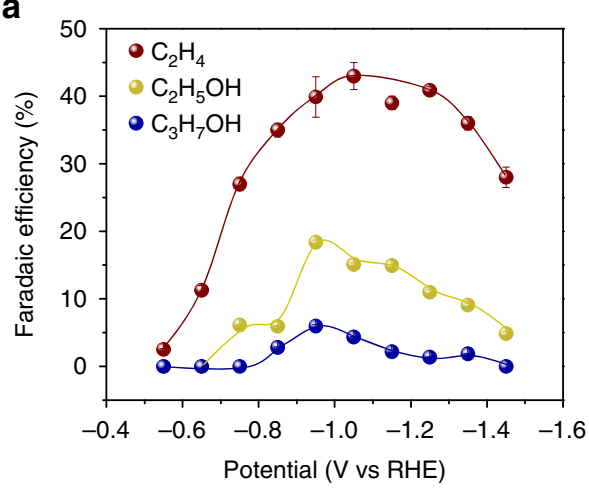

C

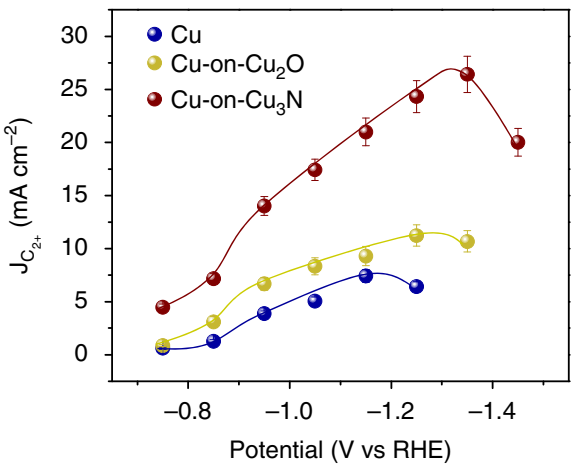

b

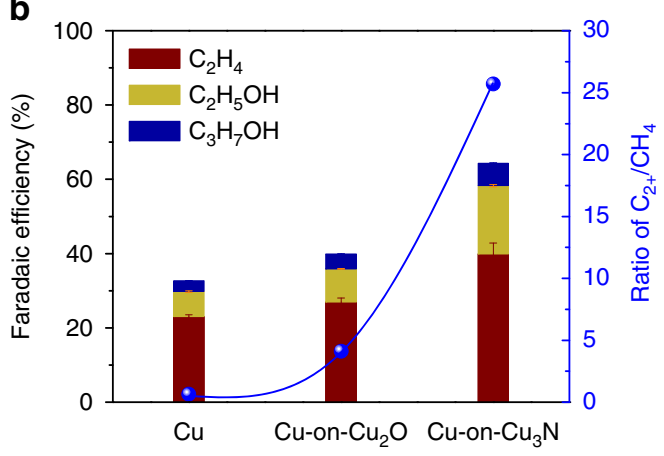

d

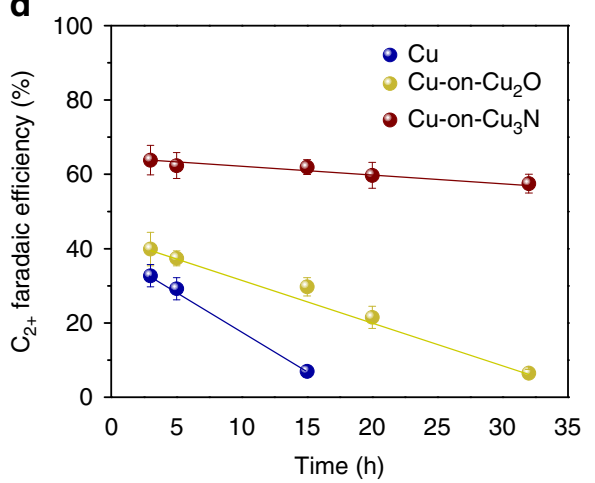

Fig. $4 \mathrm{CO}_{2}$ electroreduction performance of the designed catalysts. a Faradaic efficiency of the $\mathrm{C}_{2+}$ distribution on $\mathrm{Cu}_{-}-\mathrm{on}-\mathrm{Cu}_{3} \mathrm{~N}$ at different potentials. b Comparison of faradaic efficiency for $\mathrm{C}_{2+}$ and the ratio of $\mathrm{C}_{2+} / \mathrm{CH}_{4}$ at $-0.95 \mathrm{~V}$ vs $\mathrm{RHE}$ on $\mathrm{Cu}$, Cu-on- $\mathrm{Cu}_{2} \mathrm{O}$, and $\mathrm{Cu}_{-}$on- $\mathrm{Cu}_{3} \mathrm{~N}$. c $\mathrm{C}_{2+}$ partial current density at different potentials on the three catalysts. $\mathbf{d}$ Stability test of $\mathrm{C}_{2+}$ selectivity on the three catalysts. Experiments from a to $\mathbf{d}$ were performed in triplicates and the results are shown as mean \pm standard deviation

enhancement over pure $\mathrm{Cu}$ (Fig. 4b) $\mathrm{CH}_{4}$ production is thus strongly suppressed for the catalysts that use $\mathrm{Cu}_{2} \mathrm{O}$ and $\mathrm{Cu}_{3} \mathrm{~N}$ support compared with pure $\mathrm{Cu}$ (Supplementary Fig. 13b-c and Supplementary Tables 3-4).

To further compare the $\mathrm{CO}_{2}$ reduction activity of the three samples, we obtained $\mathrm{C}_{2}$ partial current densities at a variety of potentials between -0.75 and $-1.45 \mathrm{~V}$ vs RHE (Fig. 4c). The Cu-on$\mathrm{Cu}_{3} \mathrm{~N}$ catalyst exhibits a higher $\mathrm{C}_{2}$ partial current density relative to $\mathrm{Cu}$-on- $\mathrm{Cu}_{2} \mathrm{O}$ and pure $\mathrm{Cu}$ across the entire potential window, with a maximum $14 \mathrm{~mA} \mathrm{~cm}^{-2}$ at $-0.95 \mathrm{~V}$ vs RHE, $2.2 \mathrm{x}$ and $4.4 \mathrm{x}$ higher than $\mathrm{Cu}-\mathrm{on}-\mathrm{Cu}_{2} \mathrm{O}$ and pure $\mathrm{Cu}$ catalysts, respectively.

To test the operational stability of the catalysts, we carried out $\mathrm{CO}_{2}$ reduction over an extended period of time. The $\mathrm{Cu}-$ on- $-\mathrm{Cu}_{3} \mathrm{~N}$ catalyst exhibits relatively stable Faradaic efficiencies toward $\mathrm{C}_{2} \mathrm{H}_{4}, \mathrm{C}_{2} \mathrm{H}_{5} \mathrm{OH}$, and $\mathrm{C}_{3} \mathrm{H}_{7} \mathrm{OH}$, with a relative $10 \%$ decrease following $30 \mathrm{~h}$ of continuous $\mathrm{CO}_{2}$ electroreduction (Fig. $4 \mathrm{~d}$ and Supplementary Fig. 15). We attribute this superior stability to the suppressed reduction of the $\mathrm{Cu}_{3} \mathrm{~N}$ support over time, such that the beneficial effect of the $\mathrm{Cu}_{3} \mathrm{~N}$ support is sustained over this longer operating time. In contrast, $\mathrm{Cu}$-on- $\mathrm{Cu}_{2} \mathrm{O}$ catalyst shows a loss of about $25 \%$ relative of its selectivity following $15 \mathrm{~h}$, while pure $\mathrm{Cu}$ shows decreased $\mathrm{C}_{2+}$ production following $5 \mathrm{~h}$ of $\mathrm{CO}_{2}$ reduction (Fig. 4d).

\section{Discussion}

Recent studies have suggested that the $\mathrm{CO}_{2}$ reduction performance of oxide-derived $\mathrm{Cu}$ catalysts can be ascribed to local $\mathrm{pH}$ and to derived surface defects ${ }^{19,21,22}$. Compared to pure $\mathrm{Cu}, \mathrm{Cu}$-on- $\mathrm{Cu}^{+}$ catalysts display a suppression in methane selectivity, which can be attributed to increased local $\mathrm{pH}$. Comparing $\mathrm{Cu}$-on- $\mathrm{Cu}_{2} \mathrm{O}$ and $\mathrm{Cu}-$ on- $\mathrm{Cu}_{3} \mathrm{~N}$ catalysts, the geometric current densities are similar
(Supplementary Fig. 16), which indicates a nearly identical consumption rate of local protons during $\mathrm{CO}_{2}$ reduction. We propose therefore that differences in local $\mathrm{pH}$ do not account for the higher $\mathrm{C}_{2+}$ selectivity for $\mathrm{Cu}$-on- $\mathrm{Cu}_{3} \mathrm{~N}$ relative to $\mathrm{Cu}$-on- $\mathrm{Cu}_{2} \mathrm{O}$.

We also considered surface defects as another possible contributing mechanism. For the $\mathrm{Cu}$-on- $\mathrm{Cu}_{2} \mathrm{O}$ catalyst, we believe that surface defects-grain boundaries-may influence the selectivity toward $\mathrm{C}_{2+}$ in the case of the oxide-derived process. For the $\mathrm{Cu}-$ on- $\mathrm{Cu}_{3} \mathrm{~N}$ catalyst, surface defects can also affect the $\mathrm{C}_{2+}$ selectivity. However, compared with $\mathrm{Cu}-\mathrm{on}-\mathrm{Cu}_{2} \mathrm{O}$, which was quickly derived to $\mathrm{Cu}$ (Fig. $3 \mathrm{~d}$ ), the $\mathrm{Cu}$-on- $\mathrm{Cu}_{3} \mathrm{~N}$ catalyst retained a higher $\mathrm{C}_{2+}$ selectivity under $\mathrm{CO}_{2}$ reduction. We offer that suppressed reduction of the $\mathrm{Cu}_{3} \mathrm{~N}$ support thus plays a significant part in the high selectivity over the course of $\mathrm{CO}_{2}$ reduction.

Single-crystal studies have also shown that the exposed $\mathrm{Cu}$ facets affect selectivity ${ }^{45-47}$. In this work, we synthesized three catalysts using an initial electroreduction of the surface oxidation layer using a negative cyclic voltammetry $(\mathrm{CV})$ scan. During this process, the $\mathrm{Cu}$ species possess a polycrystalline structure (Supplementary Fig. 17). These structures do not exhibit the specific facet orientation. Therefore, we would not expect that these would contribute in a quantitatively significant way to increase $\mathrm{C}_{2+}$ selectivity.

Taking these findings together with those from XPS (including ARXPS and VBS), in situ XAS, and HRTEM-EELS, we propose that the $\mathrm{Cu}^{+}$support may play a role in selectivity toward $\mathrm{C}_{2+}$. Due to the change of surface structure with time evolution, the surface $\mathrm{Cu}$ layer is no longer uniform and some of $\mathrm{Cu}^{+}$may reside in the subsurface layer during the initial reduction (Supplementary Fig. 6), favouring selectivity for $\mathrm{C}_{2+} \cdot \mathrm{Cu}_{3} \mathrm{~N}$ as the support stabilizes the $\mathrm{Cu}^{+}$to a greater degree than does $\mathrm{Cu}_{2} \mathrm{O}$ during $\mathrm{CO}_{2}$ reduction (Fig. 3d), leading to heightened $\mathrm{C}_{2+}$ production. 
To understand the role of $\mathrm{Cu}^{+}$support in $\mathrm{Cu}^{0}$-on- $\mathrm{Cu}^{+}$composite catalyst for $\mathrm{CO}_{2}$ reduction, we performed density functional theory (DFT) computations to calculate the oxidation state of the surface $\mathrm{Cu}$ in the models: $\mathrm{Cu}, \mathrm{Cu}_{3} \mathrm{~N}, \mathrm{Cu}_{2} \mathrm{O}, \mathrm{Cu}-\mathrm{on}-\mathrm{Cu}_{3} \mathrm{~N}$, and $\mathrm{Cu}-$ on- $\mathrm{Cu}_{2} \mathrm{O}$ (Supplementary Figs. 18-22). Bader charge analyses show that both $\mathrm{Cu}_{2} \mathrm{O}$ and $\mathrm{Cu}_{3} \mathrm{~N}$ as $\mathrm{Cu}^{+}$supports modulate the partial oxidation state of the surface copper layer (Supplementary Table 5), with +0.03 extra charge induced by $\mathrm{Cu}_{2} \mathrm{O}$ support and +0.25 by $\mathrm{Cu}_{3} \mathrm{~N}$ support on (100) facet, respectively, different from that of pure $\mathrm{Cu}(0)$, pure $\mathrm{Cu}_{2} \mathrm{O}(+0.26)$, and pure $\mathrm{Cu}_{3} \mathrm{~N}(+0.47)$ on (100) facet. This modulated partial oxidation state enables $\mathrm{Cu}$ on- $\mathrm{Cu}_{3} \mathrm{~N}$ to achieve the lowest $\mathrm{CO}$ dimerization barrier energy $(0.884 \mathrm{eV})$ among all models (Supplementary Figs. 23-24 and Supplementary Table 5), thereby indicating promise as a candidate for $\mathrm{C}_{2+}$ production. To evaluate further the selectivity of these catalysts for $\mathrm{C}_{2+}$ products compared to the competing $\mathrm{C}_{1}$ products, we also calculated the energy barriers for $\mathrm{CO}$ protonation (Supplementary Methods). The results reveal that the energy barrier for the $\mathrm{C}_{1}$ pathway for $\mathrm{Cu}-\mathrm{on}-\mathrm{Cu}_{3} \mathrm{~N}(0.933 \mathrm{eV})$ is higher than that of $\mathrm{Cu}-\mathrm{on}-\mathrm{Cu}_{2} \mathrm{O}(0.749 \mathrm{eV})$ and pure $\mathrm{Cu}(0.721 \mathrm{eV})$ on (100) facets (Supplementary Table 5).

Since, the stability of the sublayer $\mathrm{Cu}^{+}$is important, we studied the diffusion free energy barrier for nitrogen and oxygen from their original positions in the $\mathrm{Cu}_{3} \mathrm{~N}$ and $\mathrm{Cu}_{2} \mathrm{O}$ structures, respectively, to the surface of $\mathrm{Cu}-\mathrm{on}-\mathrm{Cu}_{3} \mathrm{~N}$ and $\mathrm{Cu}-\mathrm{on}-\mathrm{Cu}_{2} \mathrm{O}$ with $4 \mathrm{Cu}$ top layers. Although there is a large energy barrier $(>2 \mathrm{eV})$ for both $\mathrm{O}$ and $\mathrm{N}$ to leave their original position, there is no more diffusion barrier for $\mathrm{O}$ from the first layer to the surface (Supplementary Figs. 25-26 and Supplementary Table 6). However, for $\mathrm{N}$ we observe another energy barrier $(\sim 1 \mathrm{eV})$ to diffuse to the surface (Supplementary Fig. 27 and Supplementary Table 6). This agrees with our observations throughout that $\mathrm{N}$ in the sublayer is more stable than $\mathrm{O}$.

In summary, the present work introduces a Cu-based catalyst that enables metallic $\mathrm{Cu}$-on- $-\mathrm{Cu}_{3} \mathrm{~N}$ to promote the production of $\mathrm{C}_{2+}$ species. $\mathrm{Cu}_{3} \mathrm{~N}$ was chosen as the inner support to modify the electronic structure of the surface metal, affecting thereby the adsorption and dimerization of intermediate $\mathrm{CO}$ properly in the $\mathrm{CO}_{2}$ reduction. Together with the suppressed reduction of $\mathrm{Cu}^{+}$using $\mathrm{Cu}_{3} \mathrm{~N}$ as the support, we were able to achieve higher selectivity for $\mathrm{C}_{2+}$ formation using $\mathrm{Cu}$-on- $\mathrm{Cu}_{3} \mathrm{~N}$ compared to the case of $\mathrm{Cu}-\mathrm{on}-\mathrm{Cu}_{2} \mathrm{O}$ and pure $\mathrm{Cu}$.

\section{Methods}

Synthesis of $\mathrm{Cu}_{3} \mathbf{N}$ nanocrystals. Quantity of $0.15 \mathrm{~g}$ of $\mathrm{Cu}\left(\mathrm{NO}_{3}\right)_{2} \cdot 3 \mathrm{H}_{2} \mathrm{O}$ and $4.3 \mathrm{~g}$ of 1-octadecylamine (ODA) was dissolved in $15 \mathrm{~mL}$ of 1-octadecene. The solution was degassed for $10 \mathrm{~min}$ at $150^{\circ} \mathrm{C}$. The temperature was then raised to $240{ }^{\circ} \mathrm{C}$ and kept for another $10 \mathrm{~min}$. When it cooled down to room temperature, the product was collected by centrifugation, washed with hexane/acetone (1/4) three times, and finally dispersed in hexane.

Transformation of $\mathrm{Cu}_{3} \mathbf{N}$ to $\mathbf{C u O}-o n-\mathrm{Cu}_{3} \mathbf{N}$. We used the ligand exchange method in ambient air to achieve the transformation of $\mathrm{Cu}_{3} \mathrm{~N}$ to $\mathrm{CuO}-$ on $-\mathrm{Cu}_{3} \mathrm{~N}$. Ten milligrams of $\mathrm{Cu}_{3} \mathrm{~N}$ nanocrystals with organic ligands was dissolved in $1 \mathrm{~mL}$ of hexane $\left(10 \mathrm{mg} \mathrm{L}^{-1}\right)$, while $10 \mathrm{mg}$ of sodium azide $\left(\mathrm{NaN}_{3}\right)$ was dissolved in $1 \mathrm{~mL}$ of NMF $\left(10 \mathrm{mg} \mathrm{L}^{-1}\right)$. The two solutions were then mixed and stirred overnight. The nanocrystals gradually transferred to NMF. The bottom phase was extracted and washed with hexane three times. The $\mathrm{N}_{3}{ }^{-}$-capped $\mathrm{Cu}_{3} \mathrm{~N}$ nanocrystals were then precipitated out using chloroform as the anti-solvent. The precipitate was dried in vacuum for $15 \mathrm{~min}$ and then stored. In the ligand exchange process, we deliberately exposed the materials to ambient air to introduce an oxide layer at the surface of $\mathrm{Cu}_{3} \mathrm{~N}$ nanocrystals.

Transformation of CuO-on- $\mathrm{Cu}_{3} \mathbf{N}$ to $\mathbf{C u}-$ on- $\mathrm{Cu}_{3} \mathbf{N}$. We conducted the initial electroreduction for the $\mathrm{CuO}-\mathrm{on}-\mathrm{Cu}_{3} \mathrm{~N}$ sample by sweeping the cyclic voltammetry (CV) curve from 0 to $-1.75 \mathrm{~V}$ vs RHE at a rate of $50 \mathrm{mV} \mathrm{s}^{-1}$, yielding the Cu-on$\mathrm{Cu}_{3} \mathrm{~N}$ catalyst.

Synthesis of control $\mathrm{Cu}-o n-\mathrm{Cu}_{2} \mathrm{O}$ and pure $\mathrm{Cu}$ catalysts. $\mathrm{Cu}_{2} \mathrm{O}$ and $\mathrm{Cu}$ nanocrystals were synthesized using $0.5 \mathrm{~g}$ of $\mathrm{Cu}\left(\mathrm{NO}_{3}\right)_{2} \cdot 3 \mathrm{H}_{2} \mathrm{O}$ and $0.05 \mathrm{~g}$ of $\mathrm{Cu}$
$\left(\mathrm{NO}_{3}\right)_{2} \cdot 3 \mathrm{H}_{2} \mathrm{O}$ instead, respectively, while keeping other experimental conditions the same as in the synthesis of $\mathrm{Cu}_{3} \mathrm{~N}$ nanocrystals. The ligand exchange and initial electroreduction processes were the same as in the case of the $\mathrm{Cu}-\mathrm{on}-\mathrm{Cu}_{3} \mathrm{~N}$ catalyst.

Working electrode preparation. Ten milligrams of the catalyst was dispersed in $1 \mathrm{~mL}$ of methanol, including with $20 \mu \mathrm{L}$ of Nafion solution (anhydrous, $5 \mathrm{wt} \%$ ) by sonicating for $30 \mathrm{~min}$. Twenty microliter of the homogeneous solution was then loaded on a glassy carbon electrode. The geometric surface area was $0.19 \mathrm{~cm}^{2}$. The electrode was dried in ambient air for the subsequent $\mathrm{CO}_{2}$ electroreduction test.

Electrochemical measurement. Electrochemical tests were performed in a two-compartment $\mathrm{H}$-cell. A proton exchange membrane (Nafion 117) was used. The electrolyte was $30 \mathrm{~mL}$ of $0.1 \mathrm{M} \mathrm{KHCO}_{3}$ solution saturated with $\mathrm{CO}_{2}$ gas in the cathode part for at least $30 \mathrm{~min}$ prior to the $\mathrm{CO}_{2}$ reduction test. Platinum was used as the counter electrode and $\mathrm{Ag} / \mathrm{AgCl}$ as the reference electrode (saturated with $3.0 \mathrm{M} \mathrm{KCl}, \mathrm{BASi}$ ). The glassy carbon electrode loaded with the catalyst served as the working electrode. Liner sweep voltammetry (LSV) with a scan rate of $50 \mathrm{mV} / \mathrm{s}$ was conducted first. The gas products were detected using a gas chromatograph (GC, PerkinElmer Clarus 600) equipped with a thermal conductivity detector (TCD) for hydrogen $\left(\mathrm{H}_{2}\right)$ quantification and a flame ionization detector (FID) for methane $\left(\mathrm{CH}_{4}\right)$ and ethylene $\left(\mathrm{C}_{2} \mathrm{H}_{4}\right)$. Liquid products were quantified using ${ }^{1} \mathrm{H}$ nuclear magnetic resonance (NMR, Agilent DD2 500). The NMR samples were prepared by mixing $0.5 \mathrm{~mL}$ of electrolyte with $0.1 \mathrm{~mL}$ of deuterated water $\left(\mathrm{D}_{2} \mathrm{O}\right)$, and $0.02 \mu \mathrm{L}$ of dimethyl sulfoxide (DMSO) was added as an internal standard. Potential $E$ was converted to the RHE reference electrode using:

$$
E(\text { versus RHE })=E(\text { versus } \mathrm{Ag} / \mathrm{AgCl})+0.197 \mathrm{~V}+0.059 \mathrm{~V} \times \mathrm{pH} .
$$

Electrochemical active surface area (ECSA) measurement. We used the double layer capacitance method to measure the surface roughness factors $\left(R_{\mathrm{f}}\right)$ for the samples relative to polycrystalline $\mathrm{Cu}\left(R_{\mathrm{f}}=1\right)$ foil. $R_{\mathrm{f}}$ was calculated from the ratio of the double-layer capacitance $\mathrm{C}$ of the catalyst electrode and $\mathrm{Cu}$ foil electrode $\left(\mathrm{C}_{\mathrm{Cu} \text { foil }}=29 \mu \mathrm{F}\right)$, that is, $R_{\mathrm{f}}=\mathrm{C} / \mathrm{C}_{\mathrm{Cu} \text { foil. }}$ C was determined by measuring the geometric current density at a potential at which no Faradaic process was occurring when we varied the scan rate of the $\mathrm{CV}$. CV was performed in the same electrochemical cell with $0.1 \mathrm{M} \mathrm{KHCO}_{3}$ electrolyte separated with a Nafion proton exchange membrane. The linear slope provides $\mathrm{C}$. ECSA $=R_{\mathrm{f}} \times S$, where $S$ stands for the geometric area of the glassy carbon electrode $\left(S=0.19 \mathrm{~cm}^{2}\right.$ in this work).

Characterization. XRD were measured on a Philips X'Pert Pro Super X-ray diffractometer equipped with graphite-monochromatized $\mathrm{Cu} \mathrm{Ka}$ radiation. X-ray photoelectron spectroscopy (XPS) was carried out on an ESCA Lab MKII X-ray photoelectron spectrometer. The source for excitation is $\mathrm{Mg}$ Ka radiation. For angle-resolved XPS (ARXPS), the samples were fixed on a rotatable holder, which enables measurement for take-off angles $\theta$ of $20^{\circ}$ measured relative to the surface normal. Low-resolution transmission electron microscopy (TEM) studies were performed on JEOL-2010F with an acceleration voltage of $200 \mathrm{kV}$. Highangle annular dark field scanning transmission electron microscopy (HAADFSTEM) and high-resolution transmission electron microscope electron energy loss spectroscopy (HRTEM-EELS) were carried out using a cold-field emission Cs-corrected JEOL ARM-200F Atomic Resolution Analytical Microscope operating at an accelerating voltage of $200 \mathrm{kV}$. In situ X-ray absorption of the Cu K-edges was performed at the Soft X-ray Microcharacterization Beamline (SXRMB) at Canadian Light Source (CLS). A homemade in situ electrochemical cell was used, with platinum as the counter electrode and $\mathrm{Ag} / \mathrm{AgCl}$ as the reference electrode. The electrolyte is $\mathrm{CO}_{2}$-purged $0.1 \mathrm{M} \mathrm{KHCO}_{3}$. The acquisition of each spectrum took $15 \mathrm{~min}$.

\section{Data availability}

The data that support the findings of this study are available within the article and its Supplementary Information files. All other relevant source data are available from the corresponding author upon reasonable request.

Received: 5 February 2018 Accepted: 29 August 2018

Published online: 20 September 2018

\section{References}

1. Qiao, J., Liu, Y., Hong, F. \& Zhang, J. A review of catalysts for the electroreduction of carbon dioxide to produce low-carbon fuels. Chem. Soc. Rev. 43, 631-675 (2014). 
2. Wang, Z.-L., Li, C. \& Yamauchi, Y. Nanostructured nonprecious metal catalysts for electrochemical reduction of carbon dioxide. Nano Today 11, 373-391 (2016).

3. Li, F., MacFarlane, D. R. \& Zhang, J. Recent advances in the nanoengineering of electrocatalysts for $\mathrm{CO}_{2}$ reduction. Nanoscale 10, 6235-6260 (2018).

4. Hori, Y. I. in Modern aspects of electrochemistry 89-189 (Springer, 2008).

5. Kuhl, K. P., Cave, E. R., Abram, D. N. \& Jaramillo, T. F. New insights into the electrochemical reduction of carbon dioxide on metallic copper surfaces. Energy Environ. Sci. 5, 7050-7059 (2012).

6. Peterson, A. A., Abild-Pedersen, F., Studt, F., Rossmeisl, J. \& Nørskov, J. K. How copper catalyzes the electroreduction of carbon dioxide into hydrocarbon fuels. Energy Environ. Sci. 3, 1311-1315 (2010).

7. Britovsek, G. J. et al. Iron and cobalt ethylene polymerization catalysts bearing 2, 6-bis (imino) pyridyl ligands: synthesis, structures, and polymerization studies. J. Am. Chem. Soc. 121, 8728-8740 (1999).

8. Keskin, A. \& Gürü, M. The effects of ethanol and propanol additions into unleaded gasoline on exhaust and noise emissions of a spark ignition engine. Energy Sourc. A, Recovery Util. Environ. Eff. 33, 2194-2205 (2011).

9. Papa, A. J. in Ullmann's Encyclopedia of Industrial Chemistry (Wiley-VCH Verlag GmbH \& Co. KGaA, South Charleston, 2000).

10. Atsumi, S., Hanai, T. \& Liao, J. C. Non-fermentative pathways for synthesis of branched-chain higher alcohols as biofuels. Nature 451, 86-89 (2008).

11. Yanowitz, J., Christensen, E. \& McCormick, R. L. Utilization of renewable oxygenates as gasoline blending components. (National Renewable Energy Laboratory (NREL), Golden, CO, USA, 2011).

12. Masum, B., Kalam, M., Masjuki, H., Palash, S. \& Fattah, I. R. Performance and emission analysis of a multi cylinder gasoline engine operating at different alcohol-gasoline blends. RSC Adv. 4, 27898-27904 (2014).

13. Singh, M. R., Kwon, Y., Lum, Y., Ager, J. W. III \& Bell, A. T. Hydrolysis of electrolyte cations enhances the electrochemical reduction of $\mathrm{CO}_{2}$ over Ag and Cu. J. Am. Chem. Soc. 138, 13006-13012 (2016).

14. Mistry, H. et al. Highly selective plasma-activated copper catalysts for carbon dioxide reduction to ethylene. Nat. Commun. 7, 12123 (2016).

15. Ren, D., Wong, N. T., Handoko, A. D., Huang, Y. \& Yeo, B. S. Mechanistic insights into the enhanced activity and stability of agglomerated $\mathrm{Cu}$ nanocrystals for the electrochemical reduction of carbon dioxide to npropanol. J. Phys. Chem. Lett. 7, 20-24 (2015).

16. Ren, D., Ang, B. S.-H. \& Yeo, B. S. Tuning the selectivity of carbon dioxide electroreduction toward ethanol on oxide-derived $\mathrm{Cu}_{\mathrm{x}} \mathrm{Zn}$ catalysts. ACS Catal. 6, 8239-8247 (2016).

17. De Luna, P. et al. Catalyst electro-redeposition controls morphology and oxidation state for selective carbon dioxide reduction. Nat. Catal. 1, 103-110 (2018).

18. Li, C. W. \& Kanan, M. W. $\mathrm{CO}_{2}$ reduction at low overpotential on $\mathrm{Cu}$ electrodes resulting from the reduction of thick $\mathrm{Cu}_{2} \mathrm{O}$ films. J. Am. Chem. Soc. 134, 7231-7234 (2012).

19. Verdaguer-Casadevall, A. et al. Probing the active surface sites for CO reduction on oxide-derived copper electrocatalysts. J. Am. Chem. Soc. 137, 9808-9811 (2015).

20. Li, C. W., Ciston, J. \& Kanan, M. W. Electroreduction of carbon monoxide to liquid fuel on oxide-derived nanocrystalline copper. Nature 508, 504-507 (2014).

21. Roberts, F. S., Kuhl, K. P. \& Nilsson, A. Electroreduction of carbon monoxide over a copper nanocube catalyst: surface structure and $\mathrm{pH}$ dependence on selectivity. ChemCatChem 8, 1119-1124 (2016).

22. Gupta, N., Gattrell, M. \& MacDougall, B. Calculation for the cathode surface concentrations in the electrochemical reduction of $\mathrm{CO}_{2}$ in $\mathrm{KHCO}_{3}$ solutions. J. Appl. Electrochem. 36, 161-172 (2006).

23. Gao, D. et al. Plasma-activated copper nanocube catalysts for efficient carbon dioxide electroreduction to hydrocarbons and alcohols. ACS Nano 11, 4825-4831 (2017).

24. Lee, S., Kim, D. \& Lee, J. Electrocatalytic production of C3-C4 compounds by conversion of $\mathrm{CO}_{2}$ on a chloride-induced bi-phasic $\mathrm{Cu}_{2} \mathrm{O}-\mathrm{Cu}$ catalyst. Angew. Chem. 127, 14914-14918 (2015).

25. Favaro, M. et al. Subsurface oxide plays a critical role in $\mathrm{CO}_{2}$ activation by $\mathrm{Cu}$ (111) surfaces to form chemisorbed $\mathrm{CO}_{2}$, the first step in reduction of $\mathrm{CO}_{2}$. Proc. Natl Acad. Sci. USA 114, 6706-6711 (2017).

26. Xiao, H., Goddard, W. A., Cheng, T. \& Liu, Y. Cu metal embedded in oxidized matrix catalyst to promote $\mathrm{CO}_{2}$ activation and $\mathrm{CO}$ dimerization for electrochemical reduction of $\mathrm{CO}_{2}$. Proc. Natl Acad. Sci. USA 114, 6685-6688 (2017).

27. Lum, Y. \& Ager, J. W. Stability of residual oxides in oxide-derived copper catalysts for electrochemical $\mathrm{CO}_{2}$ reduction investigated with ${ }^{18} \mathrm{O}$ labeling. Angew. Chem. Int. Ed. 57, 551-554 (2018).

28. Zhuang, T.-T. et al. Steering post-C-C coupling selectivity enables high efficiency electroreduction of carbon dioxide to multi-carbon alcohols. Nat. Catal. 1, 421-428 (2018).

29. Wang, D. et al. Structurally ordered intermetallic platinum-cobalt core-shell nanoparticles with enhanced activity and stability as oxygen reduction electrocatalysts. Nat. Mater. 12, 81-87 (2013).
30. Sasaki, K. et al. Core-protected platinum monolayer shell high-stability electrocatalysts for fuel-cell cathodes. Angew. Chem. Int. Ed. 49, 8602-8607 (2010).

31. Strasser, P. et al. Lattice-strain control of the activity in dealloyed core-shell fuel cell catalysts. Nat. Chem. 2, 454-460 (2010).

32. Lv, H. et al. A new core/shell NiAu/Au nanoparticle catalyst with Pt-like activity for hydrogen evolution reaction. J. Am. Chem. Soc. 137, 5859-5862 (2015).

33. Chen, Z. et al. Core-shell $\mathrm{MoO}_{3}-\mathrm{MoS}_{2}$ nanowires for hydrogen evolution: a functional design for electrocatalytic materials. Nano Lett. 11, 4168-4175 (2011).

34. Wang, D. et al. Pt-decorated PdCo@ Pd/C core-shell nanoparticles with enhanced stability and electrocatalytic activity for the oxygen reduction reaction. J. Am. Chem. Soc. 132, 17664-17666 (2010).

35. Wen, Z. et al. Nitrogen-enriched core-shell structured $\mathrm{Fe} / \mathrm{Fe}_{3} \mathrm{C}-\mathrm{C}$ nanorods as advanced electrocatalysts for oxygen reduction reaction. Adv. Mater. 24, 1399-1404 (2012).

36. Giordano, C. \& Antonietti, M. Synthesis of crystalline metal nitride and metal carbide nanostructures by sol-gel chemistry. Nano Today 6, 366-380 (2011).

37. Wang, D. \& Li, Y. Controllable synthesis of Cu-based nanocrystals in ODA solvent. Chem. Commun. 47, 3604-3606 (2011).

38. Liu, P. \& Hensen, E. J. Highly efficient and robust $\mathrm{Au} / \mathrm{MgCuCr}_{2} \mathrm{O}_{4}$ catalyst for gas-phase oxidation of ethanol to acetaldehyde. J. Am. Chem. Soc. 135, 14032-14035 (2013).

39. Wu, H. \& Chen, W. Copper nitride nanocubes: size-controlled synthesis and application as cathode catalyst in alkaline fuel cells. J. Am. Chem. Soc. 133, 15236-15239 (2011).

40. Avanzino, S. C. \& Jolly, W. L. A simple method for obtaining X-ray photoelectron spectra of species in liquid solution. J. Am. Chem. Soc. 100, 2228-2230 (1978)

41. Lin, Q. et al. Phase-transfer ligand exchange of lead chalcogenide quantum dots for direct deposition of thick, highly conductive films. J. Am. Chem. Soc. 139, 6644-6653 (2017).

42. Manthiram, K., Beberwyck, B. J. \& Alivisatos, A. P. Enhanced electrochemical methanation of carbon dioxide with a dispersible nanoscale copper catalyst. J. Am. Chem. Soc. 136, 13319-13325 (2014).

43. Chiang, W.-H. et al. $\mathrm{C} / \mathrm{BCN}$ core/shell nanotube films with improved thermoelectric properties. Carbon 109, 49-56 (2016).

44. Cumpson, P. J. Angle-resolved XPS and AES: depth-resolution limits and a general comparison of properties of depth-profile reconstruction methods. J. Electron. Spectrosc. Relat. Phenom. 73, 25-52 (1995).

45. Schouten, K. J. P., Qin, Z., Pérez Gallent, E. \& Koper, M. T. Two pathways for the formation of ethylene in CO reduction on single-crystal copper electrodes. J. Am. Chem. Soc. 134, 9864-9867 (2012).

46. Hori, Y., Takahashi, I., Koga, O. \& Hoshi, N. Selective formation of C2 compounds from electrochemical reduction of $\mathrm{CO}_{2}$ at a series of copper single crystal electrodes. J. Phys. Chem. B 106, 15-17 (2002).

47. Durand, W. J., Peterson, A. A., Studt, F., Abild-Pedersen, F. \& Nørskov, J. K. Structure effects on the energetics of the electrochemical reduction of $\mathrm{CO}_{2}$ by copper surfaces. Surf. Sci. 605, 1354-1359 (2011).

\section{Acknowledgements}

This work was supported financially by the Ontario Research Fund Research-Excellence Program, the Natural Sciences and Engineering Research Council (NSERC) of Canada, and the CIFAR Bio-Inspired Solar Energy program. Computations were performed on the SOSCIP Consortium's Blue Gene/Q computing platform. SOSCIP is funded by the Federal Economic Development Agency of Southern Ontario, the Province of Ontario, IBM Canada Ltd., Ontario Centres of Excellence, Mitacs and 15 Ontario academic member institutions X-ray absorption spectra were performed on SXRMB beamlines at the Canadian Light Source (CLS), which is supported by the Canada Foundation for Innovation, Natural Sciences and Engineering Research Council of Canada, the University of Saskatchewan, the Government of Saskatchewan, Western Economic Diversification Canada, the National Research Council Canada, and the Canadian Institutes of Health Research. Z.L. acknowledges a scholarship from the China Scholarship Council (CSC) (201607090041) and Basic and Innovation Program, Beijing Jiaotong University (KSJB17016536). A.S. acknowledges Fonds de Recherche du Quebec-Nature et Technologies (FRQNT) for the postdoctoral fellowship award. P.D.L. acknowledges support from NSERC in the form of the Canada Graduate Scholarship. H.T. acknowledges the Netherlands Organisation for Scientific Research (NWO) for a Rubicon grant (680-50-1511) to support his postdoctoral research at University of Toronto. The authors thank C. Q. Zou, M. X. Liu, F. F. Fan, J. Xing and L. Gao from University of Toronto for fruitful discussions.

\section{Author contributions}

E.H.S. supervised the project. Z.L. and T.Z. conceived the ideas, conducted the experiments, analyzed the results, and wrote the manuscript. A.S. carried out simulations. C.H. and P.H conducted the TEM measurements. J.L., Y.H. and Q.X. assisted in measuring XAS and analyzing the results. S.L., L.C. and C.T. assisted in analyzing the TEM results. R.Q.-B. and Y.L. performed XPS measurements. Y.Z. assisted in analyzing the XPS results. Y.W. and F.L. assisted in discussing mechanisms. P.D.L., C.T., H.T. and Y.P. assisted in revising the 
manuscript. P.C., Z.X., S.Z. and D.S. assisted in reviewing the manuscript. All authors read and commented on the manuscript.

\section{Additional information}

Supplementary Information accompanies this paper at https://doi.org/10.1038/s41467018-06311-0.

Competing interests: The authors declare no competing interests.

Reprints and permission information is available online at http://npg.nature.com/ reprintsandpermissions/

Publisher's note: Springer Nature remains neutral with regard to jurisdictional claims in published maps and institutional affiliations. (c) (i) Open Access This article is licensed under a Creative Commons Attribution 4.0 International License, which permits use, sharing, adaptation, distribution and reproduction in any medium or format, as long as you give appropriate credit to the original author(s) and the source, provide a link to the Creative Commons license, and indicate if changes were made. The images or other third party material in this article are included in the article's Creative Commons license, unless indicated otherwise in a credit line to the material. If material is not included in the article's Creative Commons license and your intended use is not permitted by statutory regulation or exceeds the permitted use, you will need to obtain permission directly from the copyright holder. To view a copy of this license, visit http://creativecommons.org/ licenses/by/4.0/.

(C) The Author(s) 2018 